\title{
A Novel DNA-Binding Protein With Regulatory and Protective Roles in Starved Escherichia Coli
}

\section{Citation}

Almirón, M., A. J. Link, D. Furlong, and R. Kolter. 1992. A Novel DNA-binding Protein with Regulatory and Protective Roles in Starved Escherichia Coli. Genes \& Development 6, no. 12B: 2646-654.

\section{Permanent link}

http://nrs.harvard.edu/urn-3:HUL.InstRepos:42640763

\section{Terms of Use}

This article was downloaded from Harvard University's DASH repository, and is made available under the terms and conditions applicable to Other Posted Material, as set forth at http:// nrs.harvard.edu/urn-3:HUL.InstRepos:dash.current.terms-of-use\#LAA

\section{Share Your Story}

The Harvard community has made this article openly available.

Please share how this access benefits you. Submit a story.

Accessibility 


\title{
A novel DNA-binding protein with regulatory and protective roles in starved Escherichia coli
}

\author{
Marta Almirón, Andrew J. Link, ${ }^{1}$ Deirdre Furlong, and Roberto Kolter ${ }^{2}$ \\ Department of Microbiology and Molecular Genetics; ${ }^{1}$ Department of Genetics, Harvard Medical School, Boston, \\ Massachusetts 02115 USA
}

\begin{abstract}
A starvation-inducible DNA-binding protein was discovered as a result of the analysis of proteins synthesized in 3-day-old cultures of Escherichia coli. This 19-kD protein, designated Dps, is abundant in starved cells. In vitro, Dps forms extremely stable complexes with DNA, without apparent sequence specificity. When complexed with Dps, DNA is rendered DNase resistant. Mutant cells lacking Dps show dramatic changes in the pattern of proteins synthesized during starvation. The mutants also fail to develop starvation-induced resistance to hydrogen peroxide, an agent that can cause oxidative damage to DNA in vivo. These results have prompted us to postulate that Dps plays an important role both in gene expression and DNA protection during stationary phase. The existence of similar proteins, heretofore with no known function, in bacterial species distantly related to Escherichia coli suggests that Dps may define a novel class of widely conserved DNA-binding proteins.
\end{abstract}

[Key Words: Stationary phase; DNA-binding protein; oxidative stress; starvation]

Received August 31, 1992; revised version accepted October 23, 1992.

The ability to maintain biological integrity during periods of starvation is essential for the survival of an organism. Many microbes have evolved sophisticated developmental pathways that lead to the formation of highly resistant differentiated cells in response to nutritional deprivation (Losick and Youngman 1984; Kjelleberg et al. 1987; Roszak and Colwell 1987; Matin et al. 1989; Siegele and Kolter 1992). Extensive studies with a variety of microorganisms have revealed changes in gene expression that occur during the transition from exponential growth to stationary phase and result in morphological and physiological changes (Groat et al. 1986; Spector et al. 1986; Connell et al. 1987; Losick et al. 1989; Bohannon et al. 1991; Lange and Hengge-Aronis 1991a; Matin 1991; Losick and Stragier 1992; Spector and Cubitt 1992).

The starved Escherichia coli cell, in contrast to a dormant spore, remains metabolically active and can quickly resume growth when the required nutrients are available (Matin 1991; Siegele and Kolter 1992). It is therefore not surprising that after the initial starvationinduced switch in gene expression, these cells maintain a low level of gene expression even after many days in stationary phase (Mandelstam 1960; Roszak and Colwell 1987). In this paper we report initial studies on the patterns of gene expression in cells that have remained starved for several days. As a result of these studies we

\footnotetext{
${ }^{2}$ Corresponding author.
}

have discovered a new DNA-binding protein, designated Dps (ㅁNA-binding protein from starved cells). The synthesis of Dps is induced upon the cessation of growth, continues even after several days of starvation, and depends on $\sigma^{\mathrm{s}}$, a transcription factor that controls the expression of many starvation-induced genes (Mulvey and Loewen 1989; Lange and Hengge-Aronis 1991b). Several of the gene products of the $\sigma^{\mathrm{s}}$ regulon have been shown to be important for the ability of the cell to develop increased resistance to environmental stresses such as high temperature, oxidative damage, and low $\mathrm{pH}$ (Hengge-Aronis et al. 1991; McCann et al. 1991).

Dps displays many of the properties of other small, abundant proteins of prokaryotic origin that bind DNA without sequence specificity (Drlica and Rouviere-Yaniv 1987; Schmid 1990). The phenotype of mutants lacking Dps suggests that it plays both regulatory and protective roles during starvation. Dps-like proteins appear to be present in distantly related eubacteria, suggesting the existence of a new family of widely conserved, DNA-binding proteins.

\section{Results}

Identification of a protein synthesized during prolonged starvation

The changes in the pattern of proteins synthesized by $E$. coli, Vibrio, and Salmonella during the transition between exponential growth and stationary phase have 
been documented extensively (Groat et al. 1986; Kjelleberg et al. 1987; Spector et al. 1988). The fact that these organisms remain metabolically active during prolonged starvation led us to investigate the proteins that they synthesize not only after a few hours of starvation but after several days in stationary phase. Newly synthesized proteins from exponential and early stationary-phase cultures can be detected, using SDS-PAGE, if the cells are labeled for $1 \mathrm{~min}$ with radioactive methionine. We discovered that, owing to their much lower metabolic rates, cells that have been starved for $\geqslant 1$ day require much longer labeling periods to detect protein synthesis. It was possible to demonstrate that such cells synthesized a distinct set of proteins when labeling periods were extended to $10 \mathrm{hr}$ (Fig. 1). It became apparent that the proteins synthesized at these later times not only differed from those made during exponential growth but also from those made during the first hours of starvation. A one-dimensional polyacrylamide gel of samples labeled at various times during the first 5 days of incubation showed continual change in the pattern of proteins synthesized (Fig. 1).

Having determined that many proteins are being synthesized in 3-day-old cultures, we wanted to identify and characterize some of them. To this end the labeled proteins were separated using two-dimensional electropho-

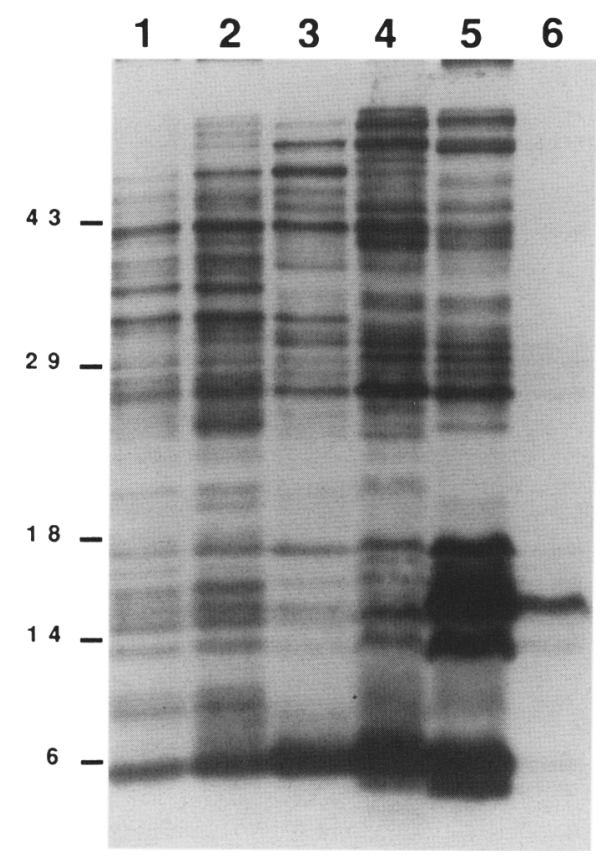

Figure 1. Protein synthesis in starved cells. Cells grown in minimal M63 medium-glucose, where growth ceased due to glucose exhaustion, were labeled with $\left[{ }^{35} S\right]$ methionine at various times during the growth curve. Samples in lanes 1-3 were labeled for $1 \mathrm{~min}$. Samples in lanes 4-6 were labeled for $10 \mathrm{hr}$. Total proteins were separated on 15\% SDS-PAGE (Laemmli 1970). Size standards are indicated (in kD). (Lane 1) Midexponential phase cells; (lane 2) late-exponential phase cells; (lane 3) early stationary phase cells; (lane 4) 1-day-old cells; (lane 5) 3-day-old cells; (lane 6) 5-day-old cells. resis and transferred to a solid support (see Materials and methods). One of the most prominently labeled protein spots displayed a molecular mass of $\sim 18,000$ daltons and was designated Dps. The spot corresponding to Dps was cleaved with trypsin, and three HPLC-purified peptides were sequenced (see Materials and methods). An exact match for one of the three peptide sequences was found when the translated GenBank data base was scanned. The match was found in a region of DNA encoding the carboxy-terminal end of a partially sequenced open reading frame of unknown function located adjacent to the glnHPQ operon in the E. coli chromosome (minute 18) (Nohno et al. 1986). A plasmid containing this region of the chromosome was kindly provided by Joan Mecsas and Carol Gross (University of Wisconsin, Madison). This plasmid pJE 106 was used to complete the sequence of the open reading frame. The gene product was predicted to contain 167 amino acids $\left(M_{\mathrm{r}} 18,712\right)$, matching the apparent molecular mass of Dps as determined by SDS-PAGE. From the completed nucleotide sequence a match for the remaining two peptides was found in the same open reading frame, further supporting the hypothesis that this region encoded Dps. To verify this and to determine the phenotype of cells lacking Dps, a null mutation in the dps gene was constructed /see Materials and methods). The presence of a kanamycin resistance gene inserted in the middle of the Dps-coding region allowed for the easy transfer of the null allele (dps::kan) to different genetic backgrounds.

\section{Phenotypes of the dps::kan null mutant}

Mutant cells lacking Dps showed a highly pleiotropic phenotype with respect to the proteins synthesized, but only during prolonged starvation (Fig. 2). In the wild-type cell, the relative amount of Dps synthesis increased dramatically in the stationary phase (Fig. 2, cf. A and C). The pattern of proteins synthesized during exponential growth in both wild-type and dps::kan strains was virtually identical, with the exception of the absence of the low level of Dps synthesized in the wild type at that time (Fig. 2, cf. A and B). In contrast, when the patterns of proteins synthesized after 3 days of starvation were compared, there were dramatic differences between the wildtype and dps::kan strains (Fig. 2, cf. C and D). The differences included both the absence, in the mutant, of proteins synthesized in the wild type at 3 days as well as the appearance of new proteins not synthesized in the wild type. These results indicate that Dps plays a global regulatory role in controlling gene expression during prolonged starvation.

When compared with growing cells, stationary-phase E. coli cells are significantly more resistant to several types of environmental assaults, including exposure to oxidative agents (Jenkins et al. 1988). Both the wild-type and the $d p s:$ :kan mutant strains rapidly lost viability when exponential-phase cells, growing in minimal medium M63 glucose, were treated with $15 \mathrm{~mm} \mathrm{H}_{2} \mathrm{O}_{2}$. Treatment of 3-day-old cultures with $45 \mathrm{~mm} \mathrm{H}_{2} \mathrm{O}_{2}$ for 40 min did not affect the viability of wild-type cells, 

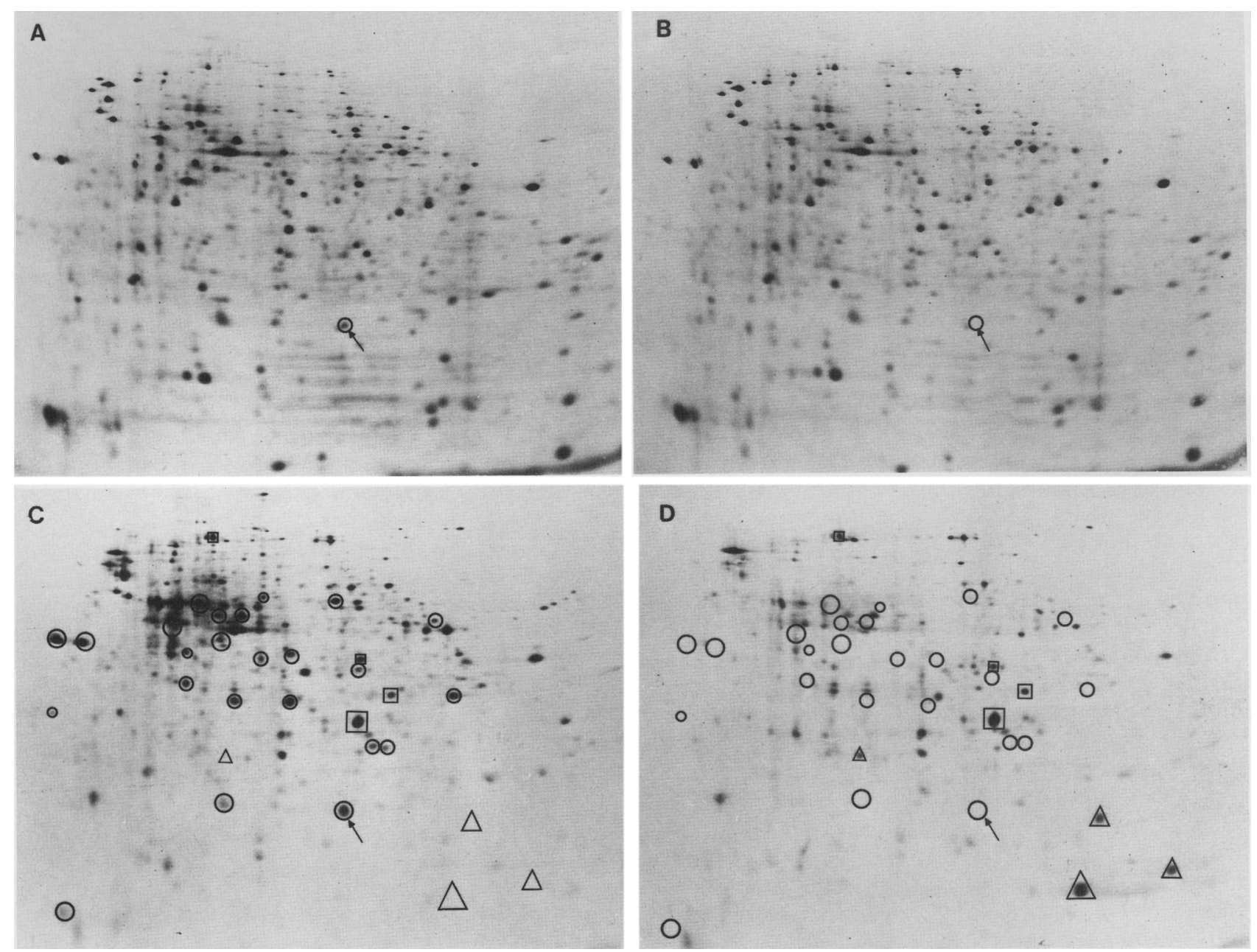

Figure 2. Pleiotropic effects of the $d p s:: k a n$ insertion mutation on protein synthesis in starved cells. Wild-type and $d p s:: k a n$ mutant cells were labeled with $\left[{ }^{35} \mathrm{~S}\right]$ methionine, and labeled proteins were separated using two-dimensional PAGE. (The molecular weight of proteins decrease from top to bottom, and $\mathrm{pH}$ decreases from left to right.) (A) Wild-type cells in midexponential phase, labeled for 1 min. (B) dps::kan mutant cells in midexponential phase, labeled for $1 \mathrm{~min}$. (C) Wild-type cells after 3 days of starvation, labeled for 10 hr. (D) dps::kan mutant cells after 3 days of starvation, labeled for $10 \mathrm{hr}$. The four arrows point to the position of Dps. To facilitate the recognition of some of the changes between wild-type and mutant cells seen at 3 days, some of the protein spots have been marked as follows: $(O)$ proteins that are present in wild-type cells but not in $d p s:: k a n$ mutant cells; $(\Delta)$ proteins missing in wild-type cells but present in the mutant; $(\square)$ proteins that have similar intensity in both types of cells. Note that the marked spots were chosen only by comparing $C$ and $D$. No consideration was given as to whether they were present or absent in exponential phase $(A$ and $B \mid$. Some of the marked spots were present in growing cells while others were not.

whereas cells lacking Dps were killed (Fig. 3). It has been shown previously that the increased resistance to hydrogen peroxide is due in part to the induction, during the onset of starvation, of hydrogen peroxidase II (HPII) (Loewen et al. 1985). However, dps::kan mutants did express normal levels of HPII, as judged by the phenotypes of colonies treated with hydrogen peroxide (Lange and Hengge-Aronis 1991b). These results suggest that in addition to its regulatory role, Dps plays a protective role directly or indirectly during starvation. Apparently the protection afforded by Dps, detected under oxidative stress, is not essential for the viability of the culture because the $d p s$ null mutants remained viable during prolonged incubation in standard laboratory media.
Two lines of evidence indicate that the observed phenotypes are due to the lack of Dps and not due to polar effects on the expression of downstream genes. First, a $d p s:: k a n$ mutant harboring a plasmid containing $d p s$ and no downstream genes was resistant to killing by $45 \mathrm{~mm}$ $\mathrm{H}_{2} \mathrm{O}_{2}$. Second, dps::kan mutants grew in minimal medium containing L-glutamine as the sole carbon source. This indicates that the expression of the downstream operon, $g \ln H P Q$, was not affected by the $d p s:: k a n$ insertion mutation (Nohno et al. 1986).

\section{Purification of Dps and properties of the protein}

To obtain more insights regarding the biochemical func- 


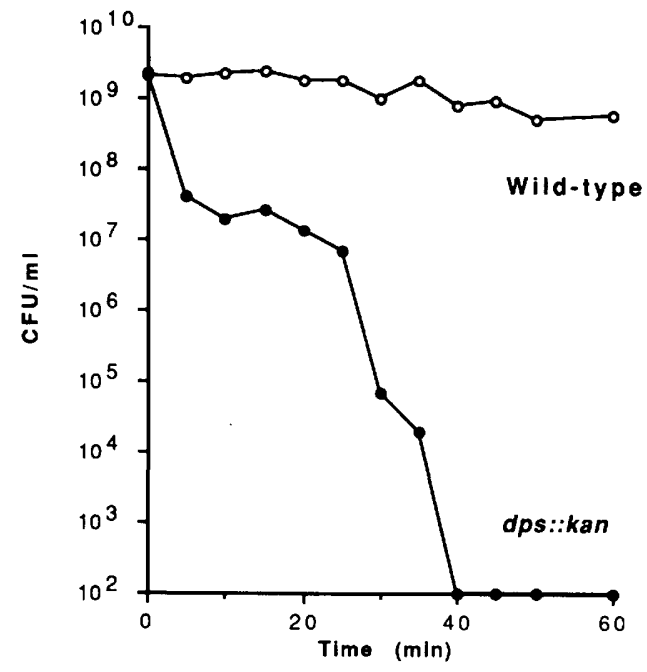

Figure 3. Hydrogen peroxide sensitivity of $d p s:: k a n$ mutant cells. Cells were starved for 3 days and then treated with $45 \mathrm{~mm}$ $\mathrm{H}_{2} \mathrm{O}_{2}$ for the indicated amounts of time. Viable counts were determined by the ability of cells to form colonies on minimal M63 medium-glucose plates.

tion of Dps, it was necessary to purify the protein. The rationale for the purification protocol was derived from two observations: (1) the apparent regulatory role of Dps in starved cells, and (2) a small but provocative region of amino acid sequence similarity with a DNA-binding protein (UL42) from herpes simplex virus (McGeoch et al. 1988; Gottlieb et al. 1990). These observations led us to hypothesize that Dps was a DNA-binding protein. This hypothesis was supported by the finding that Dps binds to DNA-cellulose and elutes at relatively high salt $10.2 \mathrm{M}$ $\mathrm{NaCl}$ ). The detailed protocol for the purification of Dps to homogeneity is presented in Materials and methods. Briefly, crude lysates were fractionated using ammonium sulfate and two steps of gel filtration. After the initial lysis of the cells, performed in $0.5 \mathrm{M} \mathrm{NaCl}$, Dps was found to be associated with DNA. Once Dps was separated from endogenous DNA and dialyzed to remove salts, it bound to DNA-cellulose. After DNA-cellulose chromatography, preparations of Dps appeared homogeneous as judged by Coomasie brilliant blue staining in SDS-PAGE (Fig. 4A). Purified Dps was subjected to amino-terminal sequence analysis, confirming the start site of translation of the $d p s$ gene. In different preparations of Dps, we detected varying amounts of a minor degradation product resulting from the loss of the first 6 residues at the amino terminus.

The binding of Dps to DNA was analyzed by studying the formation of complexes in vitro. Stable Dps-DNA complexes were detected when purified Dps was added to supercoiled plasmid DNA or linear DNA in buffer containing $10 \mathrm{~mm}$ Tris (pH 8.0) and $1 \mathrm{~mm}$ EDTA (Fig. 4B). These complexes did not enter standard Tris-acetate $1 \%$ agarose gels during electrophoresis. This feature of the complexes was used as an assay to characterize the properties of Dps-DNA complexes. These properties can be summarized as follows: (1) Complex formation was im- mediate when the $\mathrm{NaCl}$ concentration was $0.2 \mathrm{M}$ or lower. (2) The complex could be dissociated with $30 \%$ formamide or $2 \%$ SDS but not with $5 \%$ Triton X-100 or $5 \%$ Brij-58. (3) Complexes were extremely stable. No DNA exchange was detected even after $16 \mathrm{hr}$ of incubation at $65^{\circ} \mathrm{C}$. (4) Binding to DNA dramatically stabilized Dps structure. When Dps was heated at $65^{\circ} \mathrm{C}$ before complex formation, it irreversibly lost its DNA-binding capacity. However, Dps remained bound to DNA even after incubation at $100^{\circ} \mathrm{C}$. (5) Dps binds DNA without any apparent sequence specificity. No apparent "footprint" was detected after DNase I digestion. (6) Binding by Dps did not require any specific DNA size or topology. The complexes formed with similar stoichiometries, regardless of whether it was circular DNA (from 2.5 to $100 \mathrm{~kb}$ ) or linear DNA (from 0.07 to $1.3 \mathrm{~kb}$ ).

Dps and Dps-DNA complexes were analyzed further by means of electron microscopy. When Dps preparations were spread in the absence of DNA, rings of $\sim 9 \mathrm{~nm}$ in diameter were observed (Fig. 5A). In contrast to the discrete rings observed from Dps alone, the Dps-DNA complexes formed large and highly ordered two-dimensional arrays (Fig. 5B). This could be the result of a structural change that Dps undergoes when bound to DNA that allows for tighter interactions between rings, or DNA may link rings. The honeycomb arrangement of the rings in the presence of DNA and the appearance of the free rings when analyzed at higher magnification (Fig. 5A, inset) suggested a hexameric structure. Molecules lying sideways displayed a double-layered configuration (Fig. 5A, inset). The mass of the rings was $\sim 205,000$ daltons, as determined by scanning transmission electron microscopy (Wall and Hainfeld 1986). All of these observations strongly suggest that the structure

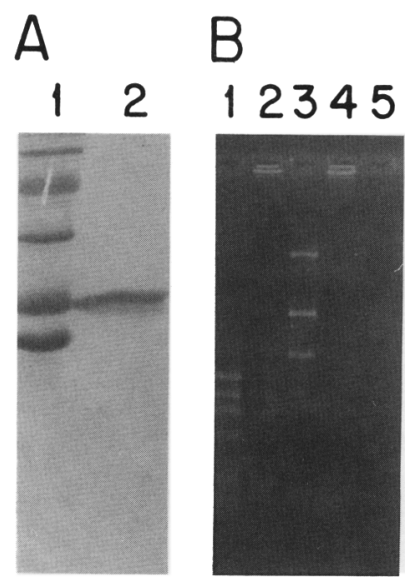

Figure 4. Purified Dps forms complexes with DNA. (A) $15 \%$ SDS-PAGE of purified Dps, stained with Coomasie brilliant blue. (Lane 1) Molecular mass standards, in ascending size (kD): 14, 18, 29, 43, 68, 97. (Lane 2) Pooled fractions containing Dps after chromatography through DNA-cellulose. $(B)$ Tris-acetate $1.0 \%$ agarose gel, DNA and DNA-Dps complexes stained with ethidium bromide. (Lane 1) $\phi$ X174 HaeIII fragments alone; (lane 2) $\phi X 174$ HaeIII fragments with Dps; (lane 3) pUC19 DNA alone; (lane 4) pUC19 DNA with Dps; (lane 5) Dps alone. 
Figure 5. Electron microscopic analysis of Dps and Dps-DNA complexes. $A$ and $B$ are at the same magnification; the inset in $A$ is magnified $2.5 \times$ more. $(A)$ Dps alone. (B) Dps-DNA complex; inset in $A$ represents a higher magnification of Dps alone, showing the hexameric ring-like structure and the double-layered structure of a ring lying sideways.
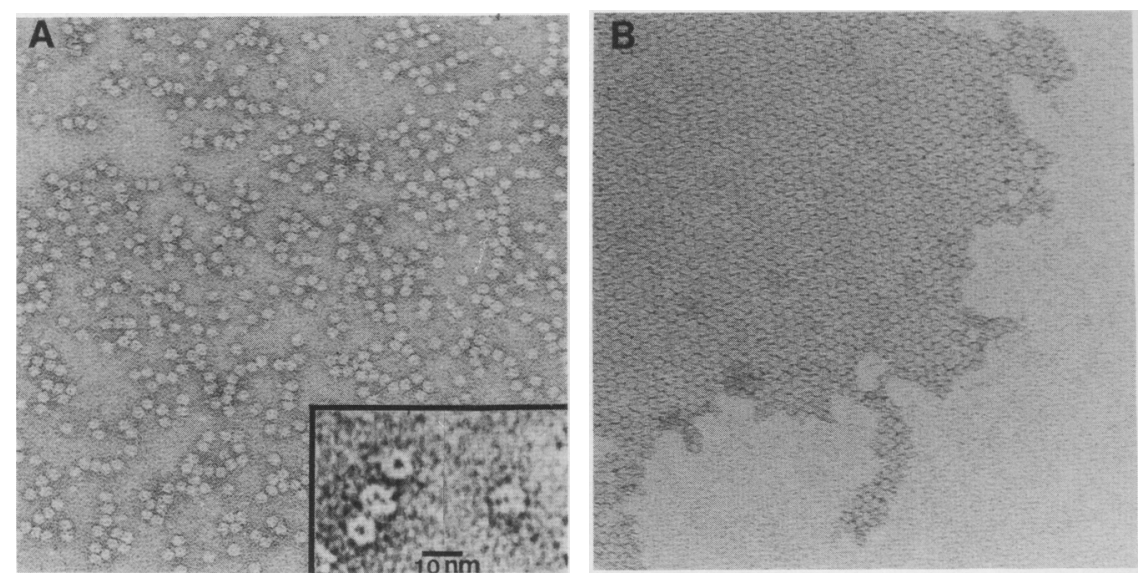

of native Dps consists of 12 subunits arranged in two hexameric rings.

\section{Expression of $d p s$ and regulation by $\sigma^{s}$}

The expression of $d p s$ was analyzed by immunological techniques. Polyclonal antibodies were raised against Dps, using purified Dps as an antigen in rabbits. Samples containing equal numbers of cells from different growth phases were subjected to SDS-PAGE and Western blot analysis (Fig. 6). In both minimal M63 glucose and in LB media, little or no Dps was detectable during exponential phase. Induction of Dps started during early stationary phase, and accumulation continued in a 1-day-old culture. On the basis of quantitative comparisons with the signal generated by known amounts of Dps, we estimated that there were $\sim 20,000$ Dps monomers in a stationary-phase cell after only $l$ day, making this a very abundant DNA-binding protein in starved cells. Finally, there was little or no detectable Dps in a strain lacking the stationary phase-specific transcription factor, $\sigma^{\mathrm{s}}$, indicating that the expression of $d p s$ is regulated, directly or indirectly, by this positive regulatory molecule.

\section{Discussion}

Growing cells have the capacity to respond rapidly to changing environments by differentially expressing sets of genes. Thus, a growing cell can cope with stresses that generate cellular damage by inducing the expression of a variety of repair genes. When a microorganism finds itself in nutritionally limiting conditions, which in nature must be most of the time, it must still be able to protect itself from environmental damage to assure its survival. A starved microorganism must prepare in advance for the possibility that it may encounter environmental assaults, as its capacity for rapid response is severely compromised. Many of the $E$. coli genes that are induced in response to starvation and whose expression depends on $\sigma^{s}$, play important roles in protecting the organism (Hengge-Aronis et al. 1991; Lange and Hengge-Aronis 1991b; McCann et al. 1991).

Clearly, protection of the cellular DNA is cardinal to the maintenance of viability and the preservation of genetic continuity. As part of the process of generating a dormant endospore, Bacillus subtilis synthesizes small acid-soluble DNA-binding proteins that protect the DNA from a variety of damaging agents (Setlow 1992). For non-sporulating organisms, such as $E$. coli, there is an additional need; they must protect their DNA, but they must also maintain a low level of gene expression during starvation. The results presented in this paper suggest that Dps plays roles connected with both of these needs, protecting the DNA from oxidative damage and affecting the global pattern of gene expression.

How does Dps protect the cell from hydrogen peroxide damage? The lethality of oxidative agents, such as hydrogen peroxide, is most likely the result of their ability to damage DNA (Storz et al. 1990). Thus, DNA repair enzymes as well as catalases, which breakdown hydrogen peroxide, play an important role in protecting the cell. One possibility is that the protective role of Dps is indirect and results from its role in regulating gene expression. For example, Dps may regulate the expression of certain DNA repair enzymes and catalases. Alternatively, Dps may protect the DNA directly. The ability of

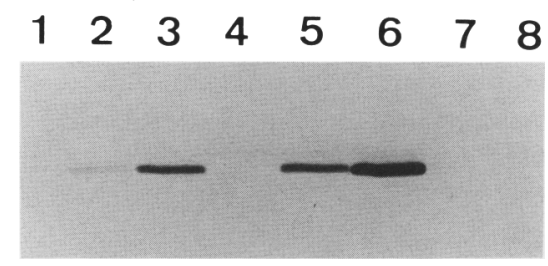

Figure 6. Western blot analysis of Dps production. An equal number of cells $\left(5 \times 10^{7}\right)$ were loaded in each lane. (Lane 1) M63-glucose-grown wild-type cells, midexponential phase; (lane 2) M63-glucose-grown wild-type cells, at the onset of stationary phase; (lane 3) M63-glucose-grown wild-type cells, 1-day-old culture; (lane 4) LB-grown wild-type cells, midexponential phase; (lane 5) LB-grown wild-type cells, at the onset of stationary phase; (lane 6) LB-grown wild-type cells, 1-day-old culture; (lane 7) M63-glucose-grown rpoS mutant cells, 1-dayold culture; (lane 8) M63-glucose-grown dps::kan mutant cells, 1-day-old culture. 
Dps to bind DNA and the fact that cells without Dps express the stationary phase-inducible catalase, HPII, are consistent with the possibility that protection is afforded directly by Dps. Dps may physically protect the DNA by covering some exposed regions and rendering them less accessible to oxidative agents. The ring structures of Dps are well suited to mask and thus protect the DNA /Fig. 5). Intriguingly, another ring-shaped protein, which has also been proposed to function by masking a macromolecule, is the GroEL chaperonin (Nilsson and Anderson 19911.

It is not yet known how Dps binds DNA. The twodimensional nature of the Dps-DNA arrays supports the hypothesis that the rings act as spools, with the DNA wound around them. Alternatively, DNA may pass through the Dps rings, in a manner analogous to what has been proposed for the interaction between the DNA polymerase III processivity factor $\beta$ and DNA (Kong et al. 1992). Studies are under way to localize the DNA within the two-dimensional arrays of Dps.

Dps is a small, abundant protein that binds DNA without apparent sequence specificity. These are properties of histone-like proteins, such as HU and H-NS iDrlica and Rouviere-Yaniv 1987; Schmid 1990). The global effects on gene expression in mutants lacking Dps are also reminiscent of the known roles of histone-like proteins, which can act both as positive or negative effectors in different systems (Drlica and Rouviere-Yaniv 1987; Schmid 1990). The concentration of H-NS increases slightly during stationary phase (Spassky et al. 1984) and mutants lacking H-NS show pleiotropic effects on gene expression during stationary phase, whereas viability was not affected (Higgins et al. 1988). However, Dps does not share amino acid sequence or structural similarities with either HU, H-NS, or any of the histone-like proteins (Kano et al. 1985, 1987; Pon et al. 1988). As such, Dps appears to define a new class of DNA-binding protein with perhaps a novel motif for non-sequence-specific DNA binding.

When the existing data bases were searched for sequence similarities with Dps, two strikingly similar proteins of heretofore unknown function were found (Fig. 7). One is an antigen from Treponema pallidum (Noordhoek et al. 1989) and the other is a protein from Anabaena variabilis (Sato 1991). Dps and these two proteins are all about the same length and the amino acid similarities are found along the entire length of the protein, although they are most similar in the central region. In addition, a partial open reading frame, coding for a hypothetical protein of $\leqslant 150$ residues located adjacent to a bromoperoxidase structural gene in Streptomyces aureofaciens (Pelletier et al. 1992), also predicts a protein of similar sequence. In pairwise comparisons these proteins contain homologous regions of $115-152$ residues that range from $23 \%$ to $30 \%$ identical and from $62 \%$ to $78 \%$ similar when conservative changes are taken into account. The central region of the four proteins contains a 57-residue stretch, where 12 residues are identical. These proteins come from bacteria distantly related to $E$. coli (Woese 1987), suggesting that Dps-like proteins are
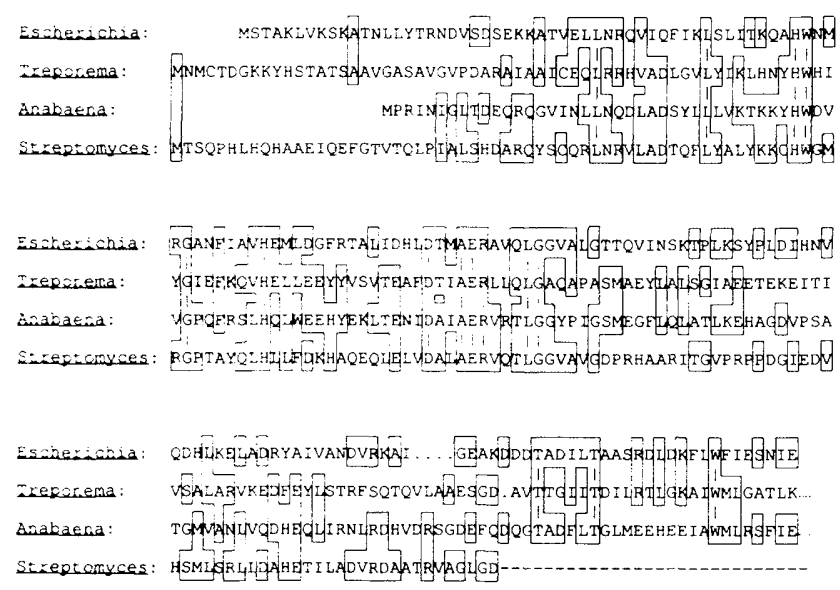

Figure 7. Alignment of the amino acid sequence of Dps with similar proteins found in the data base. The boxed residues represent identities in at least two members of the group.

highly conserved among eubacteria. The possible function of the other three proteins has not been studied. Nonetheless, there is an indication that they may not just be similar at the level of the amino acid sequence but may be functionally related to Dps because the protein from Treponema has been shown to form rings similar in size to those found for Dps (Fehniger et al. 1986). A deeper understanding of the roles of these various proteins will be revealed with continued analysis of their properties and the phenotypes of mutants unable to synthesize them.

\section{Materials and methods}

\section{Bacterial strains, plasmids, and media}

Our "wild-type" E. coli strain is ZK126 (W3110 tna-2 $\Delta$ lacU169) (Connell et al. 1987). JC7623 (arg ara his leu pro recB21 recC22 $s b c B 15$ thr) was used to recombine the dps::kan mutation into the chromosome (Winans et al. 1985). Competent cells 71-18, ZK126, and ZK126 dps::kan were used for transformation (Maniatis et al. 1989). ZK1000 is ZK126 rpoS::kan (rpoS was formerly called katF|(Bohannon et al. 1991).

Plasmids pJE100 and pJE106 (kindly provided by J. Mecsas and C. Gross, University of Wisconsin, Madison) are pBR322 derivatives that carry $E$. coli chromosomal DNA fragments of 3.8 and $1.5 \mathrm{~kb}$, respectively, and contain the entire $d p s$ gene. Plasmid pUC19 (Yanisch-Perron et al. 1985) and $\phi X 174$ (Sanger et al. 1977a) HaeIII digests were tested for in vitro DNA binding.

Minimal M63 $(0.2 \%$ glucose), LB, and MOPS $(0.5 \%$ glutamine) media were prepared as described (Miller 1972; Neidhardt et al. 1974). When necessary, kanamycin $(50 \mu \mathrm{g} / \mathrm{ml})$ or ampicillin $(150 \mu \mathrm{g} / \mathrm{ml})$ was added. All cultures were incubated at $37^{\circ} \mathrm{C}$ with aeration. Cultures of $\mathrm{ZK} 126$ grown to saturation in minimal M63 $(0.2 \%$ glucose $)$ medium, where growth ceases as a result of starvation for carbon, reach a density of $\sim 2 \times 10^{9}$ colony-forming units per $\mathrm{ml}(\mathrm{CFU} / \mathrm{ml})$. Under the conditions used, there is no appreciable drop in the number of viable cells during the first 2 weeks of incubation.

Total proteins were labeled by adding $15 \mu \mathrm{Ci} / \mathrm{ml}$ of $\left[{ }^{35} \mathrm{~S}\right] \mathrm{me}$ thionine (Amersham, SJ.1515; $1200 \mathrm{Ci} / \mathrm{mmole}$ ). A one-minute pulse was used for exponential-phase cells and a 10-hr pulse was 
used for cells under prolonged starvation. The rate of $\left[{ }^{35} S \mid \mathrm{me}\right.$ thionine incorporation into protein during the exponential phase remains linear for $\sim 3 \mathrm{~min}$, whereas the incorporation remains linear for $\geqslant 1$ day in cells under prolonged starvation. Thus, pulse lengths were chosen to ensure that $\left[{ }^{35} S \mid\right.$ methionine incorporation was linear throughout the labeling period and that the relative extent of label incorporation was roughly comparable in the different samples.

\section{Electrophoresis}

One-dimensional polyacrylamide gels SDS-polyacrylamide gels (15\%) (30:0.8 acrylamide/bisacrylamide) were prepared for separation of total proteins as described by Laemmli (1970). All samples were centrifuged, and pellets were resuspended in Laemmli sample buffer. Samples were boiled for $10 \mathrm{~min}$ before loading onto the gel. Gels were fixed, dried, and used to expose Kodak XAR film.

Preparation of protein extracts for two-dimensional electrophoresis ZK126 cultures were grown for the desired times in minimal M63 medium-glucose. A portion $(800 \mu 1)$ of the culture was centrifuged and washed with $10 \mathrm{mM} \mathrm{MgCl}_{2}$, and $1 \mathrm{mM}$ Tris- $\mathrm{HCl}(\mathrm{pH}$ 7.4). The cells were lysed with $10 \mu \mathrm{l}$ of lysis buffer [50 mM Tris- $\mathrm{HCl}$ (pH 6.8), 2\% SDS, 5\% (vol/vol) glycerol, $5 \%$ [vol/vol) $\beta$-mercaptoethanol] and heated to $95^{\circ} \mathrm{C}$ for $4 \mathrm{~min}$. The lysate was quickly placed on ice, and $1 \mu \mathrm{l}$ of $10 \mathrm{mg} / \mathrm{ml}$ DNase I/RNase was added and incubated for $20 \mathrm{~min}$. The lysate was mixed with $90 \mu$ l of solubilizer solution [ $9 \mathrm{M}$ urea, $4 \%$ NP-40, $2 \%$ Servalyt $(\mathrm{pH} 8-10)$ carrier ampholytes, $1 \%$ DTT $)$ and stored at $-70^{\circ} \mathrm{C}$.

Two-dimensional electrophoresis of E. coli extracts Twodimensional electrophoresis was performed using the method described previously (Tempst et al. 1990), with the following modifications. First-dimensional isoelectric focusing (IEF) was in $150 \times 1.5$-mm tube gels containing $3.3 \%$ polyacrylamide, $2 \% \mathrm{NP}-40,9 \mathrm{M}$ urea, and $2 \%$ (wt/vol) blend of carrier ampholytes [50\% Resolyte (pH 4-8) and 50\% Servalyt (pH 5-7)]. Second-dimensional SDS-PAGE was in $160 \times 150 \times 1.5-\mathrm{mm}$ slab gels containing $20 \%$ acrylamide, $0.71 \mathrm{~m}$ Tris $-\mathrm{HCl}(\mathrm{pH} 8.8)$, and $0.1 \%$ SDS. The electrode buffer was $0.05 \mathrm{M}$ Tris, $0.394 \mathrm{M}$ glycine, and $0.1 \%$ SDS. The gels were run at a constant current of $60 \mathrm{~mA}$ per gel until the tracking dye had run off the lower edge of the gel.

For detection of DNA, 1\% of agarose gels were run in TAE buffer and stained with ethidium bromide (Maniatis et al. 1989). When DNA-Dps complexes were prepared, DNA in the range of $25-100 \mathrm{ng}$ was mixed with $0.5-2.5 \mu \mathrm{g}$ of protein in $10 \mathrm{~mm}$ Tris- $\mathrm{HCl}$ (pH 8.0), 1 mm EDTA buffer.

\section{Amino acid sequence determination}

Thirty-five microliters of the E. coli protein extract was loaded onto the first-dimensional IEF and purified by two-dimensional electrophoresis. The second-dimension SDS-PAGE was electrotransferred to nitrocellulose, and the proteins were detected by staining with Ponceau S as described previously (Tempst et al. 1990). The identical spot from four membranes was excised and pooled. In situ digestion with $1 \mu \mathrm{g}$ of trypsin was performed on the proteins, and released tryptic peptides were purified by reverse-phase HPLC using a $2.1 \times 20$-mm Aquapore RP-300 column (Applied Biosystems) exactly as described previously (Aebersold et al. 1987; Tempst et al. 1990). Purified peptides were sequenced using an Applied Biosystems model 477A Sequenator, and liberated PTH amino acids were detected using an online 120A HPLC system optimized for subpicomole PTH analysis (Tempst and Riviere 1989).

\section{Purification of Dps}

A 1-liter culture of ZK126 carrying the plasmid pIE106, which had been incubated for 4 days in M63 glucose, was centrifuged for $10 \mathrm{~min}$ at $5000 \mathrm{~g}$. The pellet was resuspended in buffer A [50 mM Tris (pH 8), $500 \mathrm{~mm} \mathrm{NaCl}, 0.1 \mathrm{~mm}$ EDTA]. Cells were lysed using a French press and centrifuged for $15 \mathrm{~min}$ at $30,000 \mathrm{~g}$; the supernatant was centrifuged again for $20 \mathrm{~min}$ at $100,000 \mathrm{~g}$.

Proteins found in the $100,000 \mathrm{~g}$ supernatant were precipitated using $30 \%, 60 \%$, and $90 \%$ saturated ammonium sulfate solution (SAS) cuts. Dps precipitated in the $60-90 \%$ SAS cut. The precipitate was resuspended in $1 \mathrm{ml}$ of buffer $A$ and loaded onto a $30 \times 1.5 \cdot \mathrm{cm}$ Sephadex G-100 column equilibrated with the same buffer. Dps-DNA complexes eluted in the void volume $\left(V_{0}\right)$. The fractions containing Dps were brought to $90 \%$ SAS, and the pellet was then resuspended in buffer $B[50 \mathrm{mM}$ Tris $[\mathrm{pH}$ 8), $2 \mathrm{M} \mathrm{NaCl}, 0.1 \mathrm{~mm}$ EDTA], to dissociate Dps from the DNA. Dps was separated from DNA by chromatography through a Sepharose $6 \mathrm{~B}$ column $(30 \times 1.5 \mathrm{~cm})$ with buffer B. Fractions containing Dps were pooled and dialyzed against buffer $\mathrm{C}$ [50 mM Tris (pH 8), $50 \mathrm{~mm} \mathrm{NaCl}, 0.1 \mathrm{~mm}$ EDTA].

The final step of the purification was developed as a test of the ability of Dps to bind DNA. A $10 \times 1-\mathrm{cm}$ column of DNAcellulose (Sigma) was equilibrated in buffer $C$. Pooled and dialyzed fractions from the Sepharose 6B column were loaded. After washing with three column volumes, elution was performed with a gradient from $50 \mathrm{~mm}$ to $1 \mathrm{M} \mathrm{NaCl}$; Dps eluted at $\sim 200$ $\mathrm{mm} \mathrm{NaCl}$. The fractions containing Dps did not contain any other proteins, as judged by Coomasie brilliant blue staining of SDS-PAGE.

\section{Western blotting}

Polyclonal rabbit antibodies were raised against purified Dps by contract with Eastacres Biologicals (Southbridge, MA). The crude serum was cleaned by preadsorbing with acetone powder prepared from the dps::kan strain (Harlow and Lane 1988). After electrophoresis of total proteins in one dimension, proteins were electroblotted to nitrocellulose membrane. Immunochemical detection was made by the peroxidase reaction using the Vectastain $\mathrm{ABC}$ kit and 4-chloro-1-naphthol as substrate, according to the manufacturer's protocol.

\section{DNA sequencing}

Plasmid pJE100 was purified using QIAGEN columns (Qiagen, Inc., Chatsworth, CA) and used as template for the sequencing method of Sanger (Sanger et al. 1977b). Three 25-mer oligonucleotides were used as primers to sequence both strands. The first primer was derived from the sequence of the gene that had already been determined (Nohno et al. 1986). The second and third primers were designed to extend the new nucleotide sequence to the 5 ' end of the gene and to sequence the complementary strand. The $d p s$ gene appears to be transcribed as a monocistronic mRNA. The complete nucleotide sequence of $d p s$, including the regulatory region upstream of the translation start site, has been submitted to GenBank under accession number X69337 and to the E. coli data base (Kenn Rudd, National Institutes of Health, Bethesda, MD).

\section{Mutant construction}

A kanamycin-resistant cassette (kan), obtained by digestion of mini-Tn10-kan (Way et al. 1984) with BamHI, was introduced into the plasmid-borne $d p s$ gene as follows: pJE106 was linearized with $\mathrm{Ncol}$, a restriction enzyme that cuts the plasmid only once, in the middle of $d p s$. Both DNAs were filled-in with the 
Klenow fragment of DNA polymerase I, before ligation (Maniatis et al. 1989), to obtain blunt ends. Strain 71-18 was transformed with the recombinant plasmid. The plasmid carrying the kan cassette was linearized with EcoRI (an enzyme that has only one restriction site in the vector) and used to transform JC7623 (Winans et al. 1985). Kanamycin-resistant, ampicillinsensitive recombinants, with the mutation integrated in the chromosome were isolated. Plvir was grown on one of these strains, and the lysate was used to transduce the mutation into ZK 126.

\section{Sensitivity to hydrogen peroxide}

One milliliter of culture was washed once with M63 buffer and resuspended in $1 \mathrm{ml}$ of the same buffer, and $\mathrm{H}_{2} \mathrm{O}_{2}$ was added to a final concentration of $15-45 \mathrm{~mm}$. This point was taken as $t_{0}$. The cells were kept at room temperature and the viability was determined by sampling and plating the culture every $10 \mathrm{~min}$ for $1 \mathrm{hr}$.

\section{Electron microscopy}

Negative staining was done by a miniaturization of a method described previously (Valentine and Green 1967); 50- $\mu$ l samples were used. The rings and the arrays have been observed both in ammonium molybdate at $\mathrm{pH} 7$ (not shown) and uranyl acetate at $\mathrm{pH} 4$ (shown in Fig, 5). The photographs were taken at $50,000 \times$ magnification on a JOEL $100 \mathrm{~B}$ electron microscope operated at $80 \mathrm{kV}$ with $50 \mu \mathrm{m}$ condensor and objective apertures.

\section{Computer searches}

Matches for the peptide sequences obtained from Dps were searched against the translated GenBank using the Molecular Biology Computer Research Resource Facility at the Dana-Farber Cancer Center. DNA and protein sequences were investigated for patterns and similarities using the AUTOSEARCH (Altschul et al. 1990) and FASTP (Lipman and Pearson 1985) programs.

\section{Acknowledgments}

We thank Joan Mecsas and Carol Gross for plasmids and Lise Riviere for expert operation of the protein sequenator. This project was supported by a grant from the National Science Foundation (DMB-8820458) to R.K. A.J.L. was supported by grant DE-FG02-87ER60565 from the Department of Energy to George M. Church.

The publication costs of this article were defrayed in part by payment of page charges. This article must therefore be hereby marked "advertisement" in accordance with 18 USC section 1734 solely to indicate this fact.

\section{References}

Aebersold, R.H., J. Leavitt, R.A. Saavedra, L.E. Hood, and S.B.H. Kent. 1987. Internal amino acid sequence analysis of proteins separated by one or two-dimensional gel electrophoresis after in situ protease digestion on nitrocellulose. Proc. Natl. Acad. Sci. 84: 6970-6974.

Altschul, S.F., W. Gish, W. Miller, E.W. Myers, and D.J. Lipman. 1990. Basic local alignment search tool. I. Mol. Biol. 215: 403-410.

Bohannon, D.E., N. Connell, J. Keener, A. Tormo, M. EspinosaUrgel, M.M. Zambrano, and R. Kolter. 1991. Stationary- phase-inducible "gearbox" promoters: Differential effects of katF mutations and the role of $\sigma^{70}$. I. Bacteriol. 173: 44824492.

Connell, N., Z. Han, F. Moreno, and R. Kolter. 1987. An E. coli promoter induced by the cessation of growth. Mol. Microbiol. 1: 195-201.

Drlica, K. and J. Rouviere-Yaniv. 1987. Histonelike proteins of bacteria. Microbiol. Rev. 51: 301-319.

Fehniger, T.E., J.D. Radolf, and M.A. Lovett. 1986. Properties of an ordered ring structure formed by recombinant Treponema pallidum surface antigen 4D. I. Bacteriol. 165: 732-739.

Gottlieb, J., A.I. Marcy, D.M. Coen, and M.D. Challberg. 1990. The herpes simplex vinus type 1 UL42 gene product: A subunit of DNA polymerase that functions to increase processivity. J. Virol. 64: 5976-5987.

Groat, R.G., J.E. Schultz, E. Zychlinsky, A. Bockman, and A. Matin. 1986. Starvation proteins in Escherichia coli: Kinetics of synthesis and role in starvation survival. J. Bacteriol. 168: 486-493.

Harlow, E. and D. Lane. 1988. Antibodies: A laboratory manual. Cold Spring Harbor Laboratory, Cold Spring Harbor, New York

Hengge-Aronis, R., W. Klein, R. Lange, M. Rimmele, and W. Boos. 1991. Trehalose synthesis genes are controlled by the putative sigma factor encoded by rpoS and are involved in stationary phase thermotolerance in Escherichia coli. J. Bacteriol. 173: 7918-7924.

Higgins, C.F., C.J. Dorman, D.A. Stirling, L. Waddell, I.R. Booth, G. May, and E. Bremer. 1988. A physiological role for DNA supercoiling in the osmotic regulation of gene expression in S. typhimurium and E. coli. Cell 52: 569-584.

Jenkins, D.E., J.E. Schultz, and A. Matin. 1988. Starvation-induced cross protection against heat or $\mathrm{H}_{2} \mathrm{O}_{2}$ challenge in Escherichia coli. J. Bacteriol. 170: 3910-3914.

Kano, Y., S. Yoshino, M. Wada, K. Yokoyama, M. Nobuhara, and F. Imamoto. 1985. Molecular cloning and nucleotide sequence of the HU-1 gene of Escherichia coli. Mol. Gen. Genet. 201: 360-362.

Kano, Y., K. Osato, M. Wada, and F. Imamoto. 1987. Cloning and sequencing of the HU-2 gene of Escherichia coli. Mol. Gen. Genet. 209: 408-410.

Kjelleberg, S., M. Hermansson, P. Mårdén, and G.W. Jones. 1987. The transient phase between growth and nongrowth of heterotrophic bacteria, with emphasis on the marine environment. Annu. Rev. Microbiol. 41: 25-49.

Kong, X., R. Onrust, M. O'Donnell, and J. Kuriyan. 1992. Threedimensional structure of the $\beta$ subunit of $E$. coli DNA polymerase III holoenzime: A sliding DNA clamp. Cell 69: 425437.

Laemmli, U.K. 1970. Cleavage of structural proteins during the assembly of the head of bacteriophage T4. Nature 227: 680685.

Lange, R. and R. Hengge-Aronis. 1991a. Growth phase-regulated expression of bolA and morphology of stationary phase Escherichia coli cells is controlled by the novel sigma factor $\sigma^{\mathrm{S}}($ rpoS). I. Bacteriol. 173: 4474-4481.

_ $1991 \mathrm{~b}$. Identification of a central regulator of stationary phase gene expression in Escherichia coli. Mol. Microbiol. 5: 49-59.

Lipman, D.J. and W.R. Pearson. 1985. Rapid and sensitive similarity searches. Science 227: 1435-1441.

Loewen, P.C., J. Switala, and B.L. Triggs-Raine. 1985. Catalase HPI and HPII in Escherichia coli are induced independently. Arch. Biochem. Biophys. 243: 144-149.

Losick, R. and P. Stragier. 1992. Crisscross regulation of celltype-specific gene expression during development in $B$. sub- 
tilis. Nature 355: 601-604.

Losick, R. and P. Youngman. 1984. Endospore formation in $\mathrm{Ba}$ cillus. In Microbial development (ed. R. Losick and L. Shapiro), pp. 63-88. Cold Spring Harbor Laboratory, Cold Spring Harbor, New York.

Losick, R., L. Kroos, J. Errington, and P. Youngman. 1989. Pathways of developmentally regulated gene expression in Bacillus subtilis. In Genetics of bacterial diversity (ed. D.A. Hopwood and K.F. Chater), pp. 221-240. Academic Press, San Diego, CA.

Mandelstam, J. 1960. The intracellular turnover of protein and nucleic acids and its role in biochemical differentiation. Bacteriol. Rev. 24: 289-308.

Maniatis, T., E.F. Fritsch, and J. Sambrook. 1989. Molecular cloning: A laboratory manual. Cold Spring Harbor Laboratory Press, Cold Spring Harbor, New York.

Matin, A. 1991. The molecular basis of carbon-starvation-induced general resistance in Escherichia coli. Mol. Microbiol. 5: 3-10.

Matin, A., E.A. Auger, P.H. Blum, and J.E. Schultz. 1989. Genetic basis of starvation survival in nondifferentiating bacteria. Annu. Rev. Microbiol. 43: 293-316.

McCann, M.P., J.P. Kidwell, and A. Matin.1991. The putative $\sigma$ factor KatF has a central role in development of starvationmediated general resistance in Escherichia coli. I. Bacteriol. 173: 4188-4194.

McGeoch, D.J., M.A. Dalrymple, A. Dolan, D. McNab, L.J. Perry, P. Taylor, and M.D. Challberg. 1988. Structures of Herpes Simplex virus type 1 genes required for replication of virus DNA. I. Virol. 62: 444-453.

Miller, J.H. 1972. Experiments in molecular genetics. Cold Spring Harbor Laboratory, Cold Spring Harbor, New York.

Mulvey, M.R. and P.C. Loewen. 1989. Nucleotide sequence of KatF of Escherichia coli suggests KatF protein is a novel $\sigma$ transcription factor. Nucleic Acids Res. 17: 9979-9991.

Neidhardt, F.C., P.L. Bloch, and D.F. Smith.1974. Culture medium for Enterobacteria. I. Bacteriol. 119: 736-747.

Nilsson, B. and S. Anderson. 1991. Proper and improper folding of proteins in the cellular environment. Annu. Rev. Microbiol. 45: 607-635.

Nohno, T., T. Saito, and J. Hong. 1986. Cloning and complete nucleotide sequence of the Escherichia coli glutamine permease operon (glnHPQ). Mol. Gen. Genet. 205: 260-269.

Noordhoek, G.T., P.W.M. Hermans, A.N. Paul, L.M. Schouls, J.J. van der Sluis, and J.D.A. van Embden. 1989. Treponema pallidum subspecies pallidum (Nichols) and Treponema pallidum subspecies pertenue (CDC 2575) differ in at least one nucleotide: Comparison of two homologous antigens. $M$. crob. Pathog. 6: 29-42.

Pelletier, I., O. Pfeifer, J. Altenbuchner, and K.-H. Van Pee. 1992. Molecular cloning and sequencing of a non haem bromoperoxidase from Streptomyces aureofaciens ATCC 10762. GenBank entry. Accession no. M84990.

Pon, C.L., R.A. Calogero, and C.O. Gualerzi. 1988. Identification, cloning, nucleotide sequence and chromosomal map location of hns, the structural gene for Escherichia coli DNA-binding protein H-NS. Mol. Gen. Genet. 212: 199202.

Roszak, D.B. and R.R. Colwell. 1987. Survival strategies of bacteria in the natural environment. Microbiol. Rev. 51:365379.

Sanger, F., G.M. Air, B.G. Barrell, N.L. Brown, A.R. Coulson, C.A. Fiddes, C.A. Hutchison, P.M. Slocombe, and M. Smith. 1977a. Nucleotide sequence of bacteriophage phi X174 DNA. Nature 265: 687-695.

Sanger, F., S. Nicklen, and A.R. Coulson. 1977b. DNA sequenc- ing with chain terminating inhibitors. Proc. Natl. Acad. Sci. 74: 5463-5467.

Sato, N. 1991 . Hypothetical $20.2 \mathrm{~K}$ protein from Anabaena variabilis. PIR entry. Accession no. JU0384.

Schmid, M.B. 1990. More than just "histone-like" proteins. Cell 63: $451-453$

Setlow, P. 1992. I will survive: Protecting and repairing spore DNA. I. Bacteriol. 174: 2737-2741.

Siegele, D.A. and R. Kolter. 1992. Life after log. I. Bacteriol. 174: 345-348.

Spassky, A., S. Rimsky, H. Garreau, and H. Buc. 1984. Hla, an $E$. coli DNA-binding protein which accumulates in stationary phase, strongly compacts DNA in vitro. Nucleic Acids Res. 12: 5321-5340.

Spector, M.P. and C.L. Cubitt. 1992. Starvation-inducible loci of Salmonella typhimurium: Regulation and roles in starvation-survival. Mol. Microbiol. 6: 1467-1476.

Spector, M.P., Z. Aliabadi, T. Gonzalez, and J.W. Foster. 1986. Global control in Salmonella typhimurium: Two-dimensional electrophoretic analysis of starvation-, anaerobiosis-, and heat shock-inducible proteins. I. Bacteriol. 168: 420424.

Spector, M.P., Y.K. Park, S. Tirgari, T. Gonzalez, and J.W. Foster. 1988. Identification and characterization of starvationregulated genetic loci in Salmonella typhimurium by using Mud-directed lacZ operon fusions. I. Bacteriol. 170: 345351 .

Storz, G., L.A. Tartaglia, S.B. Farr, and B.N. Ames. 1990. Bacterial defenses against oxidative stress. Trends Genet. 6: $363-$ 368.

Tempst, P. and L. Riviere. 1989. Examination of automated polypeptide sequencing using standard phenil isothiocyanate reagent and subpicomole high-performance liquid chromatographic analysis. Anal. Biochem. 183: 290-300.

Tempst, P., A.J. Link, L.R. Riviere, M. Fleming, and C. Elicone. 1990. Internal sequence analysis of proteins separated on polyacrylamide gels at the submicrogram level: Improved methods, applications and gene cloning stratagies. Electrophoresis 11: 537-553.

Valentine, R.C. and N.M. Green. 1967. Electron microscopy of an antibody-hapten complex. I. Mol. Biol. 27: 615-617.

Wall, J.S. and J.F. Hainfeld. 1986. Mass mapping with the scanning transmission electron microscope. Annu. Rev. Biophys. Biophys. Chem. 15: 355-376.

Way, J.C., M.A. Davis, D. Morisato, D.E. Roberts, and N. Kleckner. 1984. New Tn10 derivatives for transposon mutagenesis and for construction of $l a c Z$ operon fusions by transposition. Gene 32: 369-379.

Winans, S.C., S.J. Elledge, J.H. Krueger, and G.C. Walker. 1985. Site-directed insertion and deletion mutagenesis with cloned fragments in Escherichia coli. J. Bacteriol. 161: 12191221.

Woese, C.R. 1987. Bacterial evolution. Microbiol. Rev. 51: 221271 .

Yanisch-Perron, C., J. Vieira, and J. Messing. 1985. Improved M13 phage cloning vectors and host strains: Nucleotide sequence of the M13mp18 and pUC19 vectors. Gene 33: 103119. 


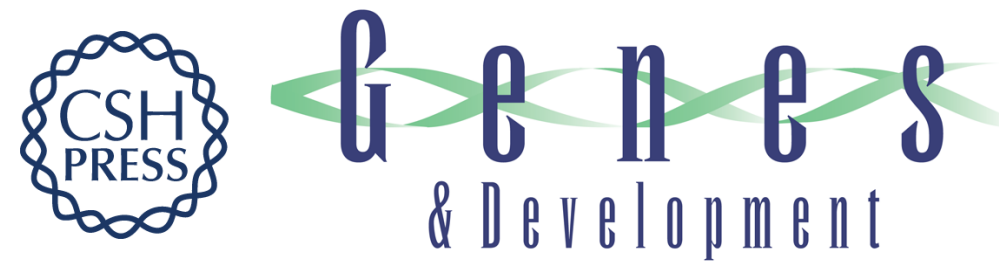

\section{A novel DNA-binding protein with regulatory and protective roles in starved Escherichia coli.}

M Almirón, A J Link, D Furlong, et al.

Genes Dev. 1992 6: 2646-2654

Access the most recent version at doi:10.1101/gad.6.12b.2646

References This article cites 51 articles, 22 of which can be accessed free at:

http://genesdev.cshlp.org/content/6/12b/2646.full.html\#ref-list-1

Email Alerting Receive free email alerts when new articles cite this article - sign up in the box at the Service top right corner of the article or click here.

To subscribe to Genes \& Development go to:

http://genesdev.cshlp.org/subscriptions 